\title{
Potential ecological distribution of alien mollusk Corbicula largillierti and its relationship with human disturbance in a semi-arid reservoir
}

\author{
Evaldo de Lira Azevêdo ${ }^{1,7}$, José Etham de Lucena Barbosa', Teofânia Heloisa Dutra Amorim Vidigal', \\ João Carlos Marques ${ }^{4}$, Marcos Callisto ${ }^{5}$ \& Joseline Molozzi ${ }^{6}$ \\ ${ }^{1}$ Universidade Estadual da Paraíba, Pós-Graduação em Ecologia e Conservação, Laboratório de Ecologia \\ de Bentos, Campina Grande, PB, Brasil. \\ ${ }^{2}$ Universidade Estadual da Paraíba, Centro de Ciências Biológicas, Programa de Pós-Graduação em \\ Ecologia e Conservação, Departamento de Biologia, Laboratório de Ecologia Aquática, Campina Grande, \\ PB, Brasil. \\ ${ }^{3}$ Universidade Federal de Minas Gerais, Departamento de Zoologia, Belo Horizonte, MG, Brasil. \\ ${ }^{4}$ Universidade de Coimbra, Faculdade de Ciências e Tecnologia, Departamento de Ciências da Vida, \\ Coimbra, Portugal \\ ${ }^{5}$ Universidade Federal de Minas Gerais, Departamento de Biologia Geral, Belo Horizonte, MG, Brasil. \\ ${ }^{6}$ Universidade Estadual da Paraíba, Centro de Ciências Biológicas, Programa de Pós-Graduação em \\ Ecologia e Conservação, Departamento de Biologia, Laboratório de Ecologia de Bentos, Campina Grande, \\ PB, Brasil. \\ ${ }^{7}$ Corresponding author: Evaldo de Lira Azevêdo, e-mail: evaldoazevedo@yahoo.com.br
}

AZEVÊDO, E.L., BARBOSA, J.E.L., VIDIGAL, T.H.D.A., MARQUES, J.C., CALLISTO, M., MOLOZZI, J. Potential ecological distribution of alien mollusk Corbicula largillierti and its relationship with human disturbance in a semi-arid reservoir. Biota Neotropica. 16(1): e0109. http://dx.doi.org/10.1590/16760611-BN-2015-0109

\begin{abstract}
The introduction of exotic mollusk species has resulted in loss of biodiversity in semi-arid neotropical aquatic ecosystems. This study aims to relate the presence and density of Corbicula largillierti species to human disturbance, providing data for the conservation and management of aquatic ecosystems. Specimens were collected at Epitácio Pessoa reservoir in December 2011 and June 2012, presenting densities of 20.96 and 62.89 individuals per square meter, respectively. Anthropic disturbance metrics were calculated considering the presence, type and intensity of disturbance in littoral, riparian and flood zones. The occurrence of $C$. largillierti was mainly associated to the variables total phosphorus $(261.05 \pm 342.22 \mu \mathrm{g} / \mathrm{L})$ and total nitrogen $(440.79 \pm 103.77 \mu \mathrm{g} / \mathrm{L})$, near to tributaries. The occurrence of exotic mollusk species is evidence of the need for freshwater ecosystem conservation and management, particularly in reservoirs used for water supply.
\end{abstract}

Keywords: Corbiculidae, anthropic disturbance, environmental quality.

AZEVÊDO, E.L., BARBOSA, J.E.L., VIDIGAL, T.H.D.A., MARQUES, J.C., CALLISTO, M., MOLOZZI, J. Potencial ecológico de distribuição do molusco alienígena Corbicula largillierti e sua relação com perturbação humana em um reservatório no semiárido. Biota Neotropica. 16(1): e0109. http://dx.doi. org/10.1590/1676-0611-BN-2015-0109

Resumo: A introdução de espécies exóticas de moluscos resulta em perda de biodiversidade em ecossistemas aquáticos semiáridos neotropicais. Este estudo tem o objetivo de relacionar a presença e densidade da espécie Corbicula largillierti ao distúrbio humano, fornecendo dados para a conservação e manejo de ecossistemas aquáticos. Os espécimes foram coletados no reservatório Epitácio Pessoa em dezembro de 2011 e junho de 2012, com densidades de 20,96 e 62,89 indivíduos por metro quadrado, respectivamente. Métricas de perturbação antrópica foram calculadas considerando a presença, tipo e intensidade de perturbação nas zonas litorânea, ribeirinha e de inundação. A ocorrência de C. largillerti esteve associada às variáveis fósforo total $(261,05 \pm 342,22 \mu \mathrm{g} / \mathrm{L})$ e nitrogênio total $(440,79 \pm 103,77 \mu \mathrm{g} / \mathrm{L})$, em locais próximos aos afluentes. A ocorrência de espécies exóticas de moluscos evidencia a necessidade de conservação e manejo de ecossistemas de água doce, principalmente em reservatórios utilizados para abastecimento de água.

Palavras-chave: Corbiculidae, distúrbio antrópico, qualidade ambiental. 


\section{Introduction}

Biological invasions threaten native species, as they modify interspecific interactions, community structure and ecosystems' natural processes (Emer \& Fonseca 2011), and thus are considered the second main cause of biodiversity loss on a global scale (Darrigran et al. 2011).

Potentially invasive exotic species typically present high growth rates, ability to develop in a wide range of habitats and high ecological plasticity (Darrigran \& Damborenea 2011). Considering that 10 to $20 \%$ of exotic species become invasive (Mcclaughlin 2002), the development of better tools for determining in advance where introduced species might become a threat is of the utmost importance. Identifying geographical distribution and the environmental factors which determine the occurrence of exotic species and forecasting species expansion are important conservation strategies (Oliveira et al. 2010, Jackson \& Britton 2013).

Freshwater bivalves are among the exotic species with high invasion potential. They have been found in ecosystems worldwide (Darrigran et al. 2011, Franco et al. 2012, Wittmann et al. 2012). Three species of such bivalves from south-eastern Asia reached the neotropic ecozone during the 1960s: Corbicula fluminea (Muller 1774), Limnoperna fortunei (Dunker 1857) and Corbicula largillierti (Philippi 1844) (Darrigran 2002). Since then, these species have invaded several aquatic ecosystems in South America. C. largillierti belongs to the Corbiculidae family (Bivalvia, Heterodonta, Veneroida), originary to China's Yangtze Kiang lake system (Mansur et al., 2004). In South America, it was recorded for the first time on the La Plata River, on the outskirts of Buenos Aires, during the 1960s (Ituarte 1981). In Brazil, it was initially recorded on the Mato Grosso Pantanal (wetlands) (Callil \& Mansur 2002), and on the Sinos River basin at Rio Grande do Sul (Mansur \& Pereira 2006), followed by recordings in hydrographical basins at Minas Gerais, Espírito Santo, Santa Catarina and northeastern Brazil (Ceará) (Silva \& Barros 2011, Santos et al. 2012) and Paraíba (Azevêdo et al. 2014).

Stronger presence of exotic species in aquatic ecosystems is usually associated with human disturbance and lower environmental quality (Olenin et al. 2007). Some species are highly tolerant to physical and chemical variations, and colonize new habitats in reservoirs as they present high reproduction rates and adapt easily to different types of environment (Ruse 2010). In this semi-arid region, aquatic ecosystems present particular dynamics because of the following features: (1) distinct climatic and geomorphological characteristics; (2) highly variable precipitation both in time and in space; (3) low temperature variation (temperatures above $25^{\circ} \mathrm{C}$ ); (4) high potential evapotranspiration, which promotes hydric deficit for about nine months per year; (5) shallow soil; (6) hydrographic basins with intermittent flow; and (7) deciduous vegetation coverage at the Caatinga biome (Barbosa et al. 2012).

Another issue that threatens conservation is the emerging diversion of water from the São Francisco River (born in Minas Gerais and extends by the states of Bahia, Sergipe, Alagoas and Pernambuco) to Paraíba River (state of Paraíba), a project by the Federal Government. Local ecological impacts, such as increased total phosphorus concentrations and proliferation of green algae are imminent ( $\mathrm{Li}$ et al. 2013). In addition, the change of direction of the water will change the regime of flooding of the Paraíba River, from flood periods variables to permanent flooding, potentially causing loss of habitat and native fauna (Kingsford 2000), such as fish, birds and benthic macroinvertebrates.

These features strongly influence aquatic ecosystems, adding to the anthropic effect, which needs the development of management plans accommodating the human use of the watershed (Pereira et al. 2013). In order to assess the interaction between human activities and the characteristics of habitats on the littoral zone of reservoirs, the United States Environmental Protection Agency (US-EPA) has developed a protocol for evaluating physical habitats (US-EPA 2011, 2012). This protocol enables the calculation of disturbance metrics for reservoirs' riparian and flood zones by considering both the extension and the intensity of anthropic disturbances (Kaufmann et al. 2014a, Kaufmann et al. 2014b).

This study relates to the presence and density of $C$. largillierti in Paraíba River's hydrographic basin with human disturbances, thus providing information that can be used in other reservoirs to establish management and conservation programs.

\section{Material and Methods}

The study area comprised the Epitácio Pessoa reservoir in the Paraíba River hydrographic basin, part of the Brazilian semi-arid region. This region's annual pluviometric index is typically lower than $400 \mathrm{~mm}$, with an aridity index of up to 0.5 and a drought risk over $60 \%$. Also, the Brazilian semi-arid region has an area of $969.589 .4 \mathrm{~km}^{2}$ and a population of over 22 million people, and is the world's most populated semi-arid region (Pereira-Junior 2007). The Epitácio Pessoa reservoir

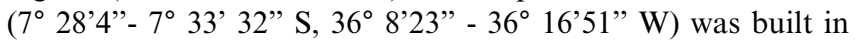
1956 and has a hydric capacity of over 418 million $\mathrm{m}^{3}$, its residence time is three to five years (AESA 2013) because of long dry periods, which favours the retention of nutrients and sediments from its drainage basin (Freitas et al. 2011).

C. lagillierti specimens were collected in sediment samples from 20 sampling sites in the reservoir's littoral zone with a Van Veen grab sampler $\left(477 \mathrm{~cm}^{2}\right)$ in December 2011 and June 2012, periods with higher and lower water volume, respectively. Taxonomic identification was performed according to shell characterization provided by Mansur et al. (2004) and Pereira et al. (2012). Identified material was later stored at the Laboratory of Malacology and Molecular Systematics at Universidade Federal de Minas Gerais (lots 3582 and 3583).

In order to apply the physical habitat characterization protocol, the methodology provided by Kauffman et al. (2014a, 2014b) was used. For each of the 20 sampling sites, the protocol was applied along 150 meters of the river bank, on ten consecutive 15 meter wide transects, thus adding up to 200 applied protocols, 10 for each site. Each sampling unit was composed of continuous littoral $(15 \times 10 \mathrm{~m})$, riparian $(15 \times 15 \mathrm{~m})$ and flood $(15 \times \mathrm{Y} \mathrm{m})$ zone sections, where $\mathrm{Y}$ stands for flood zone length, which varied according to the bank angle at each site (Figure 1). Disturbance metrics were calculated according to the method applied by the US Environmental Protection Agency (Kaufmann et al. 2014a, Kaufmann et al. 2014b). For this study, human disturbance extension and intensity indices were calculated for the riparian zone (RDix_IX, Riparian human disturbance index) and the flood zone (RDix_IX inund). Twelve types of disturbance or human activities were considered for the riparian disturbance index (RDix_IX). Four of these were related to agriculture (plantation, pasture, orchard, parks/grasslands) and 


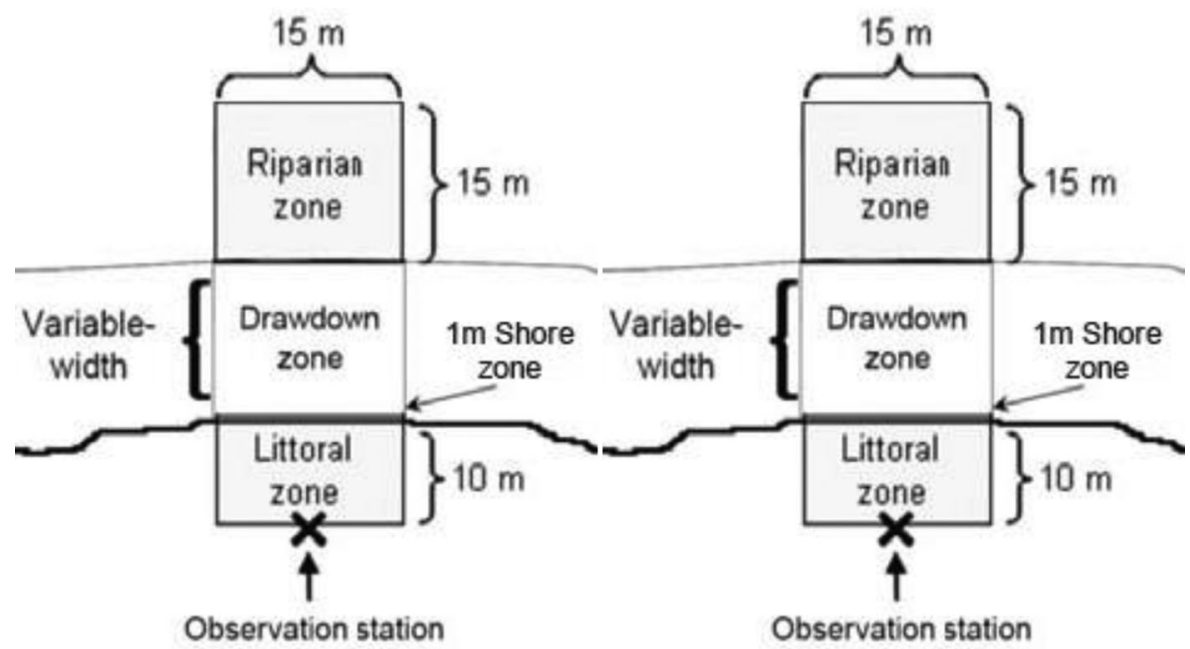

Figure 1. Outline of the observation area for application of the protocol characterization of physical habitat (US-EPA 2011.2012).

eight represented other activities which cause disturbance (buildings, commerce, ramp/artificial beach, docks/boats, walls/dams, garbage/debris, roads/railways, transmission lines). Disturbance metrics weighted disturbance according to its location in relation to the site as follows: absent disturbance had weight 0.0 , disturbance inside the site had weight 1.0 and disturbance adjacent to the site had weight 0.5 . The obtained values were then used for calculating a weighted mean. Metric indices presented final values which ranged from zero to one, with lower values representing low disturbance and higher values pointing to more intense disturbance. Flood zone metrics were calculated in the same manner. As there were two values for each site (riparian and flood zones), an arithmetical mean was calculated in order to obtain a single value using each zone's index (riparian zone and flood zone indexes).

Some variables were measured to assess water quality: temperature, $\mathrm{pH}$, electrical conductivity, turbidity, oxygen, total dissolved solids, and salinity, these measurements were performed with the aid of a multi-analyzer Horiba/U-50 and water transparency using the Secchi disk. Nutrient concentration, total phosphorus (P-total), orthophosphate $\left(\mathrm{PO}_{4}\right)$, total nitrogen (N-total), nitrate $\left(\mathrm{NO}_{3}\right)$, nitrite $\left(\mathrm{NO}_{2}\right)$, ammonia $\left(\mathrm{NH}_{4}\right)$ and alkalinity were analysed according to the Standard Methods for the Examination of Water and Wastewater (APHA 2005). Granulometric composition was assessed by sieving, according to the methodology provided by Suguio (1973) and modified by Callisto \& Esteves (1995). Sediment organic matter percentages were determined by gravimetric analysis.

Using the disturbance metrics of riparian and flood zones was performed a cluster analysis by using Euclidean distance. The metric values were the same for December 2011 and June 2012, because the evaluated human disturbances not show significant changes in such/short period of time, different from the physical and chemical parameters. After the formation of sampling site groups composed of disturbance metrics, a PERMANOVA (Dissimilarity/distance-based analysis of univariate or multivariate data in response to ANOVA experimental/sampling designs; Anderson 2001, Anderson \& Braak 2003) was performed. Another PERMANOVA analysis was used to evaluate the differences between environmental variables between the years 2011 and 2012. This analysis assesses whether formed groups differ significantly. A single factor was selected: anthropogenic disturbance (with two levels: greater disturbance and lesser disturbance); with 999 permutations and a significance level $(\alpha \leq 0.05)$. In order to identify which environmental variables influenced $C$. largillierti distribution, distance-based linear models were applied (DistLM) (Legendre \& Anderson 1999). This analysis assesses the relation between one or more predictive variables for a group of biological data from a dissimilarity matrix. To determine variables, the "Best" test was performed. This test relates environmental variables to community structure by eliminating spatial effects; thus, the method searches for the best subgroup of environmental variables capable of explaining the community structure. The "Best" test was associated with the AIC criterion, as better AIC values indicate better models. Also, for assessing the occurrence of $C$. largillierti, anthropogenic disturbance levels for each site and site locations where the bivalve was found were organized in a bar-line combination chart (Legendre \& Anderson 1999). All statistical tests were performed with PRIMER-6 + PERMANOVA softwares, Systat Software, Cranes Software International Ltd. (Ansderson et al. 2008).

\section{Results}

In 2011, C. largillierti was observed on a single location close to a tributary's confluence, presenting a density of 20.96 $\mathrm{ind} / \mathrm{m}^{2}$. In June 2012, specimens were recorded in six locations with densities of $62.89 \mathrm{ind} / \mathrm{m}^{2}$ (sites 16 and 19); $41.92 \mathrm{ind} / \mathrm{m}^{2}$ (sites 17 and 20); $20.96 \mathrm{ind} / \mathrm{m}^{2}$ (sites 10 and 18), also close tributaries (Figure 2).

Average values for disturbance metrics in flood and riparian zones were separated into two main groups: the first one contained the lowest values, indicating areas with lower disturbance, and the second group contained the highest values (Figure 3), indicating more disturbance sites. Sites with lowest and highest disturbance values were significantly different (PERMANOVA: Pseudo- $F_{1.19}=52.61 ; \mathrm{p}=0.001$ ). Sites with less anthropogenic disturbance presented values ranging from 0.0 to 0.3 , whereas more disturbance sites presented values over 0.3 . Accordingly, $20 \%$ of the sites were classified as having lesser anthropogenic disturbance, and the remaining $80 \%$ as 


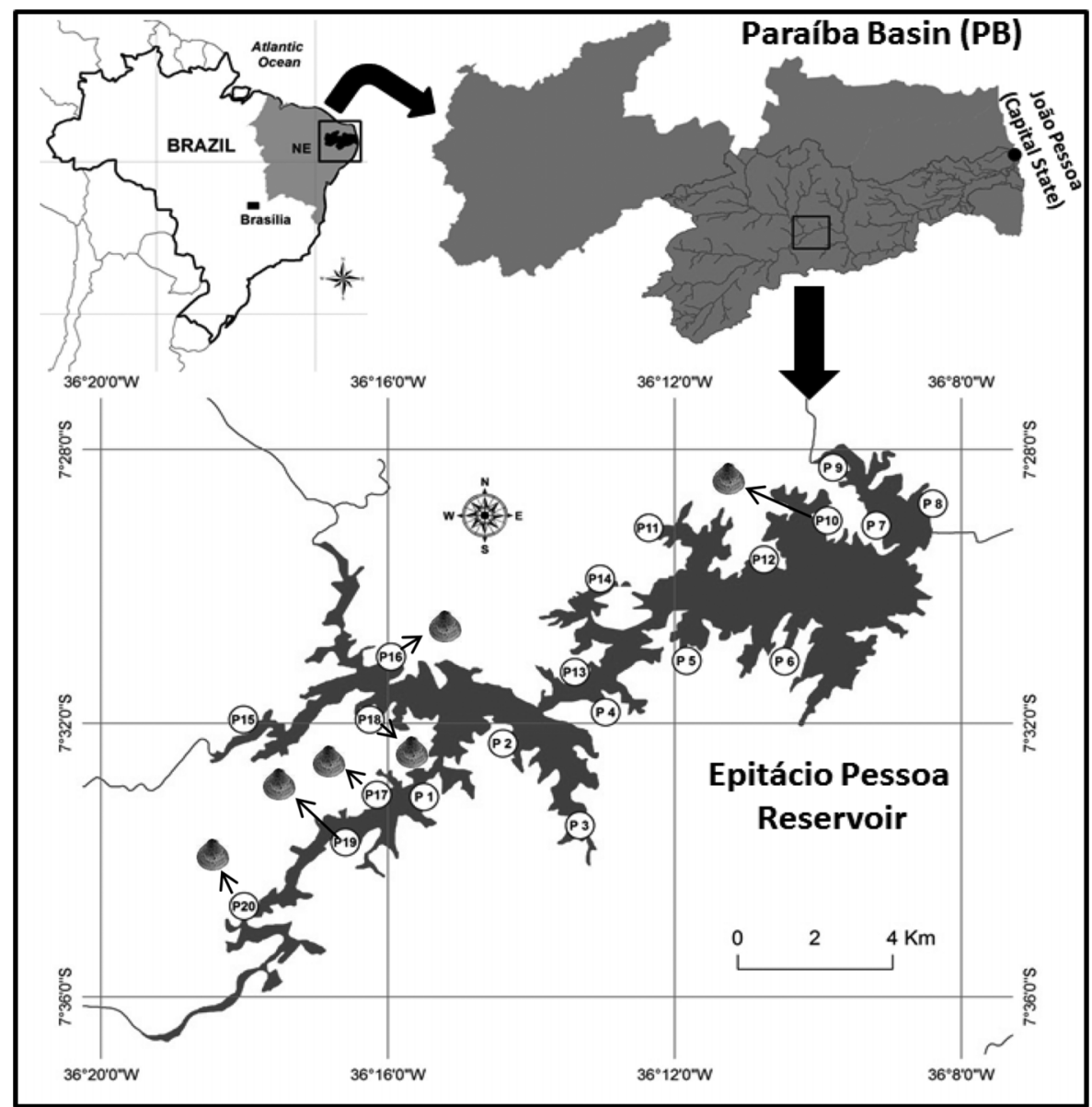

Figure 2. Distribution of Corbicula largillierti Epitácio Pessoa reservoir.

having greater disturbance. Of these last, $25 \%$ showed C. largillierti occurrence. As regards sites close to tributaries, two sites (17 and 20), although classified as having low disturbance (disturbance $<0.3$ ), showed C. largillierti (Figure 4).
DistLM analysis indicated that P-total and organic matter have determined $C$. largillierti distribution with a higher percentage $(71 \%)$ on the sampling sites (Table 1$)$. The model has also shown that P-total values significantly influenced the

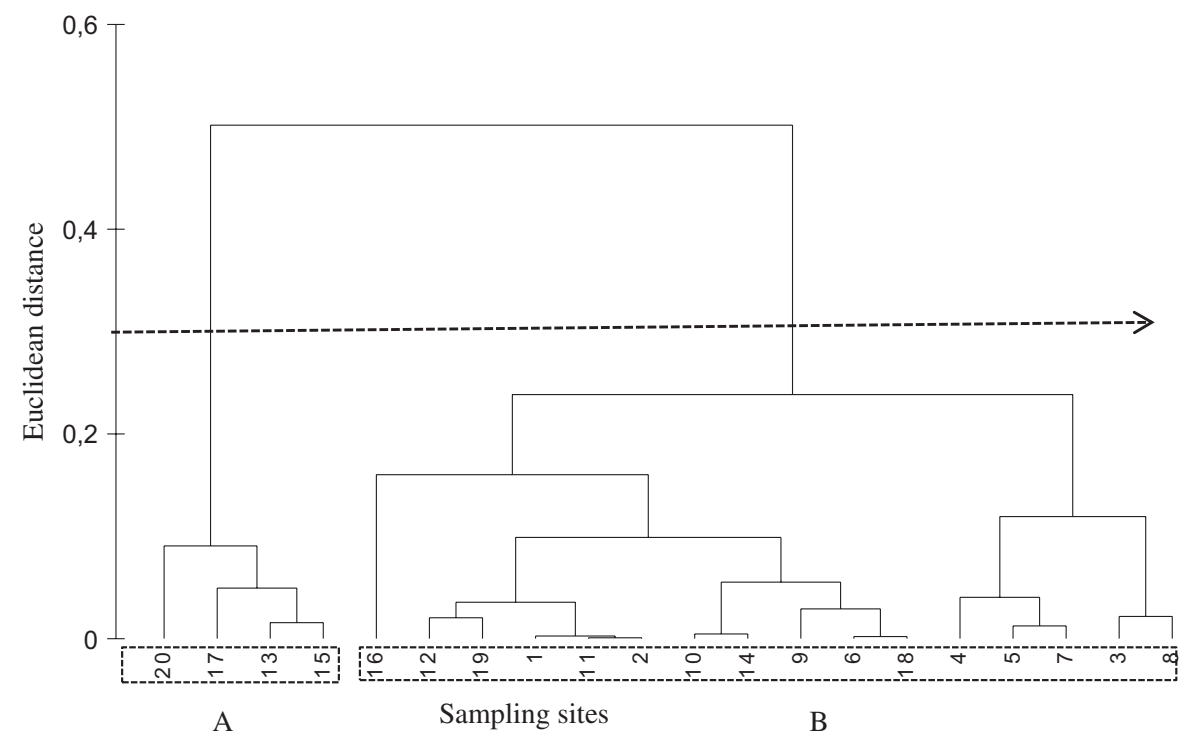

Figure 3. Dendrogram showing the clustering of the average values of the metrics of human disturbance on the sampling sites in the Epitácio Pessoa reservoir. (A) sites with lower values of metric disturbance and (B) places with higher metric disturbance. 


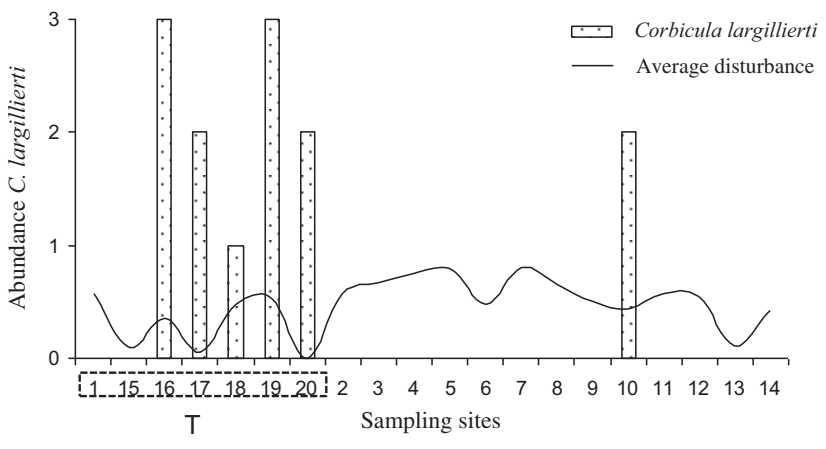

Figure 4. Sampling sites and occurrence of C. largillierti. Places near tributaries have a higher number of occurrences ( $\mathrm{T}$ represents the nearby tributaries).

bivalve distribution (49\%) when it was related to other environmental variables (Table 1).

The averages calculated for environmental variables demonstrated that groups classified as being of lesser disturbance by cluster analysis also presented lower nutrient concentration averages between the years, such as orthophosphate, total nitrogen, nitrate and nitrite (PERMANOVA: Pseudo- $\left.F_{1,39}=23.05 ; \mathrm{p}=0.001\right)($ Table 2).

\section{Discussion}

The occurrence of exotic species has increased over time because of habitat degradation and changes caused by human action (Sargent et al. 2011). C. largillierti recordings have shown that this mollusk species has reached reservoirs through tributaries, as most of the specimens were observed near confluences.

Recordings of increase in density and in the number of sampling sites with $C$. largillierti showed colonization progression in only six months (December 2011 to June 2012). Differently from other freshwater bivalve genera, Corbiculidae present high ecological and physiological plasticity, enabling their survival in a wide range of habitat conditions (Lucy et al. 2012), particularly in disturbed environments. Colonization progress in a short time is a cause for concern, as mollusks may impact the local benthic community (Santos et al. 2012, Torre \& Reyna 2013), affecting different trophic levels (Jackson \& Britton 2013) and provoking algae proliferation and substrate alteration (Everaert et al. 2011).

The $C$. largillierti prefers sites with sandy sediments, as observed in this study and also by Darrigran (2002) in studies performed on La Plata River. C. largillierti was mainly recorded on sites with thick sand sediments, indicating that the mollusk is still at an early stage of colonization; this can be inferred from the fact that interspecific competition will increase together with population and individuals will move to sites where the bottom is muddy (Torre \& Reyna 2013). Species colonization is favoured by resource availability, such as high nutrient concentration (which is generally better for exotic species) (Darrigran et al. 2011, Darrigran 2002) given that $C$. largillierti is a filter feeder species. This hypothesis is supported by higher concentrations of nutrients in sites with greater disturbance, and in 2012, including some sites near the tributaries. These regions showed variables that facilitate the emergence of mollusk (total $\mathrm{N}$ and organic matter), these variables indicate disturbance together explained $71 \%$ of species distribution along the reservoir.

In studies performed in reservoirs located in tropical climate regions in Brazil, the presence of the exotic species Melanoides tuberculata (Müller 1774) (Caenogastropoda, Thiaridae) has been recorded in sites which presented maximum ecological potential (Molozzi et al. 2013). However, affected sites have near $97 \%$ more $M$. tuberculata individuals (Schirmel \& Buchholz 2013). A similar observation was made in this work, whereby the exotic species C. largillierti was found in sites with good environmental conditions.

Sites with higher anthropogenic disturbance levels favour exotic species (Sargent et al. 2011). Apart from altering abiotic conditions and taxonomic composition, invasive species modify functional diversity, which is reflected in alterations of ecosystem functions and changes in productivity. These have consequences for ecosystem services (Schirmel \& Buchholz 2013) such as hindering water self-purification capacity (Lorenz \& Pusch 2013).

The occurrence of this mollusk makes it difficult to devise conservation efforts, especially given the transfer of water from the São Francisco River and the history of environmental degradation of the Caatinga biome (Oliveira et al. 2012). Transposition can bring new exotic species and promote the spread of $C$. largillierti to other ecosystems (Brasil 2004). A study conducted by Oliveira et al. (2010) predicted risk of exotic mollusk L. fortunei range the basin of the Rio São Francisco. In October 2015 the forecast has been confirmed, with record mollusk in the low-medium São Francisco river and transposition channel (north axis), according to Centro de Bioengenharia de Espécies Invasoras de Hidrelétricas (CBEIH 2015). This study provides an important methodology that should be considered for the management of the watershed studied, considering that the clam can reach other reservoirs in the basin, as well as natural ecosystems.

Niche modelling studies (Peterson \& Vieglais 2001), assessment of limiting factors, predicting the potential risk of introducing exotic species (Darrigran et al. 2011, Oliveira et al. 2010), and management and handling to reduce impacts caused by invasive species should be conducted to support management measures and conservation of aquatic ecosystems. It is important to know when an invader has higher odds of

Table 1. Results of the DistLM (distance-based linear models) analysis, and the environmental variables which contributed to the distribution of C. largillierti). Df (degree of freedom), $\mathrm{P}$ ( $\mathrm{p}$-value, significance), $\mathrm{R}^{2}$ (total percentage variation).

\begin{tabular}{lllr}
\hline Variables & Df & p & $\mathbf{R}^{\mathbf{2}}$ \\
\hline Total phosphorus & 5 & 0.04 & 0.49 \\
Total phosphorus / Organic matter & 5 & $0.04 / 0.13$ & 0.71 \\
Total phosphorus / Nitrate / Gravel & 5 & $0.04 / 0.05 / 0.15$ & 0.82 \\
Temperature / Oxi-redox potential / Organic matter / Grit & 5 & $0.45 / 0.004 / 0.13 / 0.01$ & 0.90 \\
Turbidity / Alkalinity / Total nitrogen / Organic matter / Grit & 5 & $0.37 / 0.08 / 0.20 / 0.13 / 0.01$ & 0.96 \\
\hline
\end{tabular}


Table 2. Mean and standard deviation values of physical and chemical variables in the sampling sites of minor and greatest disturbance, * It represents variables that showed significant differences $\leq 0,01$, between the years 2011 and 2012 .

\begin{tabular}{|c|c|c|c|c|}
\hline & \multicolumn{2}{|c|}{2011} & \multicolumn{2}{|c|}{2012} \\
\hline & Minor disturbance & Greatest disturbance & Minor disturbance & Greatest disturbance \\
\hline *Water temperature $\left({ }^{\circ} \mathrm{C}\right)$ & $29.58 \pm 0.75$ & $28.35 \pm 0.80$ & $27.09 \pm 0.93$ & $26.37 \pm 0.73$ \\
\hline *pH & $8.22 \pm 0.63$ & $7.92 \pm 0.57$ & $9.87 \pm 0.82$ & $9.04 \pm 0.51$ \\
\hline *Oxi-redox potential $(\mathrm{mV})$ & $185.50 \pm 34.81$ & $203.50 \pm 19.16$ & $86.50 \pm 28.54$ & $113.68 \pm 19.83$ \\
\hline *Electrical conductivity $(\mathrm{mS} / \mathrm{cm})$ & $0.80 \pm 0.08$ & $0.75 \pm 0.02$ & $0.88 \pm 0.02$ & $0.85 \pm 0.02$ \\
\hline Turbidity (NTU) & $132.82 \pm 142.98$ & $120.78 \pm 193.90$ & $117.77 \pm 153.23$ & $21.17 \pm 20.16$ \\
\hline Dissolved oxygen $\left(\mathrm{mg} / \mathrm{L}^{-1}\right)$ & $8.97 \pm 1.36$ & $7.69 \pm 1.90$ & $8.71 \pm 0.37$ & $8.34 \pm 1.44$ \\
\hline *Total dissolved solids $\left(\mathrm{g} / \mathrm{L}^{-1}\right)$ & $0.51 \pm 0.05$ & $0.48 \pm 0.016$ & $0.56 \pm 0.01$ & $0.54 \pm 0.01$ \\
\hline Alkalinity $\left(\mathrm{CaCo}_{3} \mathrm{mg} / \mathrm{L}^{-1}\right)$ & $17.50 \pm 5.91$ & $14.81 \pm 4.73$ & $16.00 \pm 1.14$ & $16.43 \pm 2.06$ \\
\hline *Total phosphorus -P-total $\left(\mu \mathrm{g} / \mathrm{L}^{-1}\right)$ & $1230.0 \pm 214.39$ & $996.25 \pm 154.09$ & $150.49 \pm 29.85$ & $207.68 \pm 270.69$ \\
\hline *Orthophosphate $-\mathrm{PO}_{4}\left(\mu \mathrm{g} / \mathrm{L}^{-1}\right)$ & $40.25 \pm 16.00$ & $57.12 \pm 89.19$ & $119.10 \pm 9.84$ & $127.35 \pm 6.96$ \\
\hline *Total nitrogen - N-total $\left(\mu \mathrm{g} / \mathrm{L}^{-1}\right)$ & $373.57 \pm 53.77$ & $313.25 \pm 114.18$ & $433.07 \pm 73.13$ & $452.38 \pm 95.13$ \\
\hline Ammonia- $\mathrm{NH}_{4}\left(\mu \mathrm{g} / \mathrm{L}^{-1}\right)$ & $93.77 \pm 136.49$ & $215.69 \pm 175.21$ & $609.13 \pm 868.63$ & $158.32 \pm 46.98$ \\
\hline$*$ Nitrate $-\mathrm{NO}_{3}\left(\mu \mathrm{g} / \mathrm{L}^{-1}\right)$ & $42.73 \pm 14.49$ & $47.42 \pm 12.52$ & $31.81 \pm 2.02$ & $30.69 \pm 4.80$ \\
\hline$*$ Nitrite- $\mathrm{NO}_{2}\left(\mu \mathrm{g} / \mathrm{L}^{-1}\right)$ & $3.68 \pm 1.075$ & $4.49 \pm 3.36$ & $9.61 \pm 1.43$ & $11.54 \pm 1.24$ \\
\hline Organic matter (\% P.S) & $8.34 \pm 5.81$ & $7.26 \pm 4.53$ & $7.10 \pm 2.73$ & $8.21 \pm 3.6$ \\
\hline Gravel \% $(2-64 \mathrm{~mm})$ & $13.89 \pm 18.88$ & $18.84 \pm 19.02$ & $44.95 \pm 22.75$ & $66.61 \pm 132.06$ \\
\hline${ }^{*}$ Grit $\%(1-0.50 \mathrm{~mm})$ & $21.37 \pm 14.93$ & $23.62 \pm 7.70$ & $95.38 \pm 30.27$ & $76.64 \pm 52.42$ \\
\hline *Medium sand \% $(0.250-1 \mathrm{~mm})$ & $10.69 \pm 6.31$ & $20.01 \pm 9.80$ & $36.20 \pm 16.72$ & $46.43 \pm 21.78$ \\
\hline${ }^{*}$ Fine sand $\%(0.250-0.062 \mathrm{~mm})$ & $13.86 \pm 13.28$ & $17.07 \pm 10.57$ & $41.71 \pm 17.37$ & $48.37 \pm 21.06$ \\
\hline$*$ Silt $/$ clay $\%(<0.062 \mathrm{~mm})$ & $16.87 \pm 15.75$ & $20.44 \pm 13.37$ & $154.28 \pm 167.41$ & $77.51 \pm 64.04$ \\
\hline
\end{tabular}

reaching a new environment and which places have favourable conditions for housing invasive species in order to facilitate management and conservation (Ferrari et al. 2014). Biomonitoring programs should include metrics of human disturbance, as performed in this study, and functional metrics, given that exotic species promote changes in ecosystem functioning (Lopes-Lima et al. 2014, Silva et al. 2014).

\section{Acknowledgments}

We thank the Coordenacão de Aperfeiçoamento de Pessoal de Nível Superior (Capes) for the provision of a masters scholarship that enabled the development of this work, the Universidade Estadual da Paraíba (UEPB), colleagues from the Laboratório de Ecologia de Bentos (UFMG) and Laboratório de Ecologia Aquática (UEPB). MC was awarded research productivity grants CNPq (No. 302960/2011-2) and Minas Gerais researcher grant FAPEMIG PPM-77/13 and PPM IX-02/2015.

\section{References}

AGÊNCIA EXECUTIVA DE GESTÃO DAS ÁGUAS DO ESTADO DA PARAÍBA. 2013. Comitê Rio Paraíba. http://www.aesa.pb. gov.br/comites/paraiba/2013. Consulted 14 July 2014.

ANDERSON, M.J., GORLEY, R.N \& CLARKE, K.R. 2008. PERMANOVA + for PRIMER: Guide to Software and Statistical Methods. PRIMER-E. Plymouth.

ANDERSON, M.J \& BRAAK C.J.F. 2003. Permutation tests for multi-factorial analysis of variance. J. Stat. Comput Simul. 73(2): 85-113, http://dx.doi.org/10.1080/00949650215733.

ANDERSON, M.J. 2001. A new method for non-parametric multivariate analysis of variance. Aust. j. ecol. 26(1):32-46, http://dx.doi.org/10.1111/ j.1442-9993.2001.01070.pp.x.

AZEVÊDO, E.L., BARBOSA, J.E.L., VIDIGAL, T.H., CALLISTO, M. MOLOZZI, J. 2014. First record of Corbicula largillierti (Philippi 1844) in the Paraiba River Basin and potential implications from water diversion of the Sao Francisco River. Biota Neotrop. 14(4):1-4.

APHA, Awwa. WEF. 2005. Standard methods for the examination of water and wastewater. American Public Health Association, American Water Works Association, and Water Environment Federation.

BARBOSA, J.E.L., MEDEIROS, E.S.F., BRASIL, J., CORDEIRO, R.S., CRISPIM, M.C.B. \& SILVA, G.H.G. 2012. Aquatic systems in semiarid Brazil: limnology and management. Acta. Limnol. Bras. 24(1): 103-118, http://dx.doi.org/10.1590/S2179-975X2012005000030.

BRASIL, 2004. Projeto de Integração do Rio São Francisco com Bacias Hidrográficas do Nordeste Setentrional. Relatório de Impacto Ambiental, elaborado pelo AGRAR meio ambiente e Ecology Brasil.

CALLIL, C.T. \& MANSUR, M.C.D. 2002. Corbiculidae in the Pantanal: history of invasion in souther and South America and biometrical data. Amazonian. 17(1/2):153-167.

CALLISTO, M. \& ESTEVES, F. 1995. Distribuição da comunidade de macroinvertebrados bentônicos em um lago amazônico impactado por rejeito de bauxita - lago Batata (Pará, Brasil). Oecol. Bras. 1(1):335-348.

CENTRO DE BIOENGENHARIA DE ESPÉCIES INVASORAS De HIDREIÉTRICAS. 2015. Boletim de Alerta n 03 - 10/Nov./2015, http://dx.doi.org/10.13140/RG.2.1.3814.3440.

DARRIGRAN, G. \& DAMBORENEA, C. 2011. Ecosystem Engineering Impact of Limnoperna fortunei in South America. Zool. Sci. 28(1):1-7, http://dx.doi.org/10.2108/zsj.28.1.

DARRIGRAN, G., DAMBORENEA, C., DRAGO, E.C., DRAGO, I.Z., \& PAIRA, A. 2011. Environmental factors restrict the invasion process of Limnoperna fortunei (Mytilidae) in the Neotropical region: a case study from the Andean tributaries. Ann. Limnol. - Int. J. Lim. 47(3):221-229, http://dx.doi.org/10.1051/limn/2011025.

DARRIGRAN, G. 2002. Potential impact of filter-feeding invaders on temperate inland freshwater environments. Biol. Invasions 4(1-2): 145-156, http://dx.doi.org/10.1023/A:1020521811416.

EMER, C. \& FONSECA R.C. 2011. Araucaria forest conservation: mechanisms providing resistance to invasion by exotic timber trees. Biol. Invasions 13(1):189-202, http://dx.doi.org/10.1007/s10530-010-9801-0.

EVERAERT, G., BOETS, P., LOCK, K., ZEROSK, S.D. \& GOETHALS, P.L.M. 2011. Using classification trees to analyze the impact of 
exotic species on the ecological assessment of ploder lakes in Flanders, Belgium. Ecol. Model. 222(14):2202-2212, http://dx.doi. org/10.1016/j.ecolmodel.2010.08.013.

FERRARI, J.R., PREISSER, E.L. \& FITZPATRICK, M.C. 2014. Modeling the spreas of invasive species using dynamics network models. Biol. invasions 16(4):949-960, http://dx.doi.org/10.1007/ s10530-013-0552-6.

FRANCO, J.N., CEIA, F.R., PATRICIO, J., MODESTO, V., THOMPSON, J MARQUES, J C. \& NETO, J.M. 2012. Population dynamics of Corbicula fluminea (Muller, 1774) in mesohaline and oligohaline habitats: Invasion success in Southern Europe estuary. Estuar. Coast. Shelf S. 112:31-39, http://dx.doi.org/10.1016/j.ecss.2011.07.014.

FREITAS, F.R.S., RIGHETTO, A.M. \& ATTAYDE, J.L. 2011. Cargas de fósforo total e material em suspensão em um reservatório do Semi-árido brasileiro. Oecol. Austral. 15(3):655-665, http://dx.doi.org/10.4257/oeco.2011.1503.16.

ITUARTE, C. 1981. Primera noticia acerca de la introducción de pelecípodos asiáticos em el área rio platense (Mollusca, Corbiculidae). Neotróp. 27(7):79-83.

JACKSON, M.C. \& BRITTON, J.R. 2013. Divergence in the trophic niche of sympatric freshwater invaders. Biol. Invasions 16(5):1095-1103, http://dx.doi.org/10.1007/s10530-013-0563-3.

KAUFMANN, P.R, HUGHES, R.M., VAN SICKLE, J, WHITTIER, T.R, SEELIGER, C.W \& PAULSEN, S.G. 2014. Lakeshore and littoral physical habitat structure: A field survey method and its precision. Lake Reserv. Manage. 30(2):157-176, http://dx.doi.org/ 10.1080/10402381.2013.877543.

KAUFMANN, P.R., PECK, D.V., PAULSEN, S.G., SEELIGER, C.W., HUGHES, R.M., WHITTIER, T.R. \& KAMMAN, N.C. 2014. Lakeshore and littoral physical habitat structure in a national lakes assessment Lake Reserv. Manage. 30(2):192-215, http://dx.doi.org/ 10.1080/10402381.2014.906524.

KINGSFORD, R.T. 2000. Ecological impacts of dams, water diversions and river management on floodplain wetlands in Australia. Austral Ecol. 25(2):109-127, http://dx.doi.org/10.1046/j.1442-9993. 2000.01036.x.

LEGENDRE P. \& ANDERSON, M.J. 1999. Distance-based redundancy analysis: testing multispecies responses in multifactorial ecological experiments. Ecol. Monograph. 69(1):1-24, http://dx.doi.org/ 10.1890/0012-9615(1999)069[0001:DBRATM]2.0.CO;2.

LI, B.S., ZHOU, P.J., WANG, X.Y., \& ZHU, L. 2013. Opportunities and eco-environmental influence of cascade hydropower development and water diversion projects in Hanjiang river basin. J. Geol. Soc. India 82(6):692-700, http://dx.doi.org/10.1007/s12594-013-0207-3.

LOPES-LIMA, M., TEXEIRA, A., FROUFE, E., LOPES, A., VARANDAS, S. \& SOUSA, R. 2014. Biology and conservation of freshwater bivalves: past, present and future perspectives. Hydrobiologia 735(1):1-13, http://dx.doi.org/10.1007/s10750-014-1902-9.

LORENZ, S. \& PUSCH, M.T. 2013. Filtration activity of invasive mussel species under wave disturbance coditions. Biol. Invasions 15(12):2681-2690, http://dx.doi.org/10.1007/s10530-013-0483-2.

LUCY, F.E., KARATAYEV, A. \& BURLAKOVA, L.B. 2012. Predictions for the spread, population density, and impacts of Corbicula fluminea in Ireland. Aquat. Invasions 7(4):465-474.

MANSUR, M.C.D. \& PEREIRA, D. 2006. Bivalves límnicos da bacia do rio dos Sinos, Rio Grande do Sul, Brasil (Bivalvia, Unionoida, Veneroida e Mytiloida). Rev. Bras. Zool. 23(4):1123-1147.

MANSUR, M.C.D., CALLIL, C.T., CARDOSO, F.R., SANTOS, C.P. \& IBARRA, J.A.A. 2004. Uma retrospectiva e mapeamento da invasão de espécies de Corbicula (Mollusca, Bivalvia, Veneroida, Corbiculidae) oriundas do sudeste asiático, na América do Sul. In: SILVA, J.S.V. \& SOUZA, R.C. C.L. (Eds.) Interrciências: Água de lastro e bioinvasão. Rio de Janeiro. p.39-58.

MCLAUGHLIN, S. 2002. Exotic species in the western United States: putting the Sonoran Floristic Province into perspective. In: Tellman B. (Eds.): Invasive exotic species in the Sonoran Region.
Tellman B (Eds.): University of Arizona Press and The ArizonaSonoran Desert Museum. University of Arizona Press and The Arizona-Sonoran Desert Museum. Tucson. p.47-62.

MOLOZZI, J., FEIO, M.J., SALAS, F., MARQUES, J.C. \& CALLISTO, M. 2013. Maximum ecological potential of tropical reservoirs and benthic invertebrate communities. Environ. Monit. Assess. 185(8): 6591-6606, http://dx.doi.org/10.1007/s10661-012-3049-3.

OLENIN, S. MINCHIN, D. \& DAUNYS, D. 2007. Assessment of biopollution in aquatic ecosystems. Mar. Pollut. Bull. 55:(7):379-394, http://dx.doi.org/10.1016/j.marpolbul.2007.01.010.

OLIVEIRA, G., ARAÚJO, M.B., RANGEL, T.F., ALAGADOR, D. \& DINIZ-FILHO, J.A.F. 2012. Conserving the Brazilian semiarid (Caatinga) biome under climate change. Biodivers. Conserv. 21(11): 2913-2926, http://dx.doi.org/10.1007/s10531-012-0346-7.

OLIVEIRA, M.D., HAMILTON, S.K. \& JACOBI, C.M. 2010. Forecasting the expansion of the invasive golden mussel Limnoperna fortunei in Brazilian and North American rivers based on its occurrence in the Paraguay River and Pantanal wetland of Brazil. Aquat. Invasions 5(1):59-73, http://dx.doi.org/10.1007/s10530-012-0373-z.

PEREIRA, D., MANSUR, M.C.D., DUARTE, L.D.S., OLIVEIRA, A.S., PIMPÃO, D.M., CALLIL, C.T., ITUARTE, C., PARADA, E., PEREDO, S., DARRIGRAN, G., SCARABINO, F., CLAVIJO, C., LARA, G., MIYAHIRA, I C., RODRIGUEZ, M.T.R. \& LASSO, C. 2013. Bivalve distribution in hydrographic regions in South America: historical overview and conservation. Hydrobiologia 735(1):1-30.

PEREIRA, D., MANSUR, M.C.D. \& PIMPÃO, D.M. 2012. Identificação e diferenciação dos bivalves límnicos invasores dos demais bivalves nativos do Brasil. In: Moluscos límnicos invasores no Brasil: biologia, prevenção e controle. SANTOS, C.P., PEREIRA, D., PAZ, I.C.P., ZURITA, M.L.L., RODRIGUEZ, M.T.R., NEHRKE, M.V. \& BERGONCI, P.E.A. (Eds.), pp. 75-185, Redes, Porto Alegre.

PEREIRA-JUNIOR, J.S. 2007. Nova delimitação do semi-árido brasileiro. Biblioteca Digital da Câmara dos Deputados, Brasília, http://bd.camara.leg.br/bd/handle/bdcamara/1604. Consulted 14 July 2014.

PETERSON, A. \& VIEGLAIS, D. 2001. Predicting species invasions using ecological niche modeling: new approaches from bioinformatics attack a pressing problem. Bioscience 51(5):363-371. http://dx.doi.org/ 10.1641/0006-3568(2001)051[0363:PSIUEN]2.0.CO;2.

RUSE, L. 2010. Classification of nutrient impact on lakes using the chironomid pupal exuvial. Ecol. Indic. 10(3):594-601, http://dx.doi.org/ 10.1016/j.ecolind.2009.10.002.

SANTOS, S.B., THIENGO, S.C., AMMON, M.F., MIYAHIRA, I.C., MANSUR, M.C. \& PEREIRA, D. 2012. Espécies de moluscos límnicos invasores no Brasil. In: Moluscos Límnicos Invasores no Brasil: biologia, prevenção e controle. MANSUR, M.C.D., SANTOS, C.P., PEREIRA, D., PAZ, I.C.P., ZURITA, M.L.L., RODRIGUEZ, M.T.R., NEHRKE, M.V. \& BERGONCI, P.E.A. (Eds.), pp. 2449. Redes, Porto Alegre.

SARGENT, L.W., GOLLADAY, A.P.C. \& OPSAHL, S.P. 2011. Physicochemical habitat association of a nativ; and a non-native crayfish in the lower Flint river, Georgia; implications for invasion success. Biol. Invasions 13(2):499-511. http://dx.doi.org/10.1007/ s10530-010-9844-2.

SCHIRMEL, J. \& BUCHHOLZ, S. 2013. Invasive moss alters patterns in life-history traits and functional diversity of spiders and carabids. Biol. Invasions (15):1089-1100, http://dx.doi.org/10.1007/ s10530-012-0352-4.

SILVA, E.C. \& BARROS, F. 2011. Macrofauna bentônica introduzida no brasil: lista de espécies marinhas e dulcícolas e distribuição atual. Oecol. Austral. 15(5):326-344, http://dx.doi.org/10.4257/ oeco.2011.1502.10.

SILVA, M.P.P.S., KAMINO, L.H.Y. \& PÔRTO K.C. 2014. Is the current network system of protected areas in the Atlantic Forest 
effective in conserving key species of bryophytes? Trop. Conserv. Sci. 7(1):61-74.

SUGUIO, K. 1973. Introdução à sedimentologia. 1 ed. Editora Edgard Blücher/EDUSP, São Paulo, 317p.

TORRE, L. \& REYNA, P. 2013. Bivalvia, Veneroidea, Corbiculidae, Corbicula largillierti (Philippi, 1844): New distribution record in the Del Valle Central basin, Catamarca Province, Argentina. Check list 9(1):165-166.
UNITED STATES ENVIRONMENTAL PROTECTION AGENCY 2011. 2012. National Lakes Assesment Field Operations Manual EPA 841-B-11-003. U.S. Environmental Protection Agency Washington. DC. WITTMANN, M.E., CHANDRA, S., REUTER, J.E., SCHLADOW, S.G., ALLEN, B.C., WEBB, K.J. 2012. The Control of an Invasive Bivalve, Corbicula fluminea, Using Gas Impermeable Benthic Barriers in a Large natural Lake. Environ. Manage. 49(6):1163-1173, http://dx.doi.org/10.1007/s00267-012-9850-5.

Received 10/09/2015

Revised 22/12/2015

Accepted 20/01/2016 